\title{
Tropical forest remnants as shelters of avian diversity within a tourism development matrix in Yucatan Peninsula, Mexico
}

\author{
Jorge E. Ramírez-Albores ${ }^{1,2}$ \& Marlín Pérez-Suárez ${ }^{1 *}$ \\ 1. Instituto de Ciencias Agropecuarias y Rurales (ICAR), Universidad Autónoma del Estado de México (UAEMex). \\ Carr. El Cerrillo-Piedras Blancas s/n. C.P. 50090, Toluca de Lerdo, Estado de México, México; mperezs@uaem.mx* \\ 2. Museo de Zoología "Alfonso L. Herrera", Departamento de Biología Evolutiva, Facultad de Ciencias, \\ Universidad Nacional Autónoma de México. Apdo. Postal 70-399. Ciudad de México, C.P. 04510, México; \\ jorgeramirez22@hotmail.com
}

Received 24-XI-2017. C Corrected 08-II-2018. Accepted 07-III-2018.

\begin{abstract}
Tropical forests have undergone extensive transformation because of increasing tourism development, in addition to historic clearing for agricultural and cattle grazing activities. Altogether, these activities have had an important effect on bird diversity, reducing the habitat available to many species. In this study, the role of tropical forest remnants located between different land use types was evaluated for species diversity, composition, and distribution of the bird community at Akumal region in Quintana Roo, Mexico. Point counts were used to quantify the avifauna by habitat, and Shannon's and Simpson's diversity index were used to determine bird diversity. Additionally, bird species were classified according to seasonality and trophic guild by type of habitat. A total of 160 species and 50 families was recorded, of which 100 species were permanent residents, 47 winter visitors and 11 transients. Mature tropical forest and tropical forest remnants had higher species richness than those of modified environments. This study supports the importance of tropical forest remnants as shelters for bird species in landscapes with tourism developments, and the relevance of these remnants to maintaining high bird diversity. Rev. Biol. Trop. 66(2): 799-813. Epub 2018 June 01.
\end{abstract}

Key words: avian community; conservation; species richness; fragmentation; Akumal; Quintana Roo.

Tourism development is an important driver of forest fragmentation in some countries in tropical areas, in addition to the historic clearing for cattle and agriculture (Bierregaard \& Stouffer, 1997; Lambin, Geist, \& Lepers, 2003). Construction of tourism developments and associated infrastructure (golf courses, residential zones, recreational parks, roads, etc.) result in fragmentation of forest habitats (Fahrig, 1997; Christ, Hillel, Matus, \& Sweeting, 2003; White et al., 2012), leaving many different shapes and sizes of forest remnants. Further, selective extraction of native vegetation and introduction of exotic species to increase the value of tourism complexes (Chettri, Chandra, Sharma, \& Jackson, 2005; Schlaepfer, Sax, \& Olden, 2011), modify plant species composition, and forest structure and complexity (vertical stratification and plant species composition). Altogether, these environmental modifications reduce the availability of habitats with suitable attributes (e.g., food resources and shelter) to forest-dependent wild fauna, including bird communities (McGarigal \& McComb, 1995; Newsome, Moore, \& Dowling, 2002; Buckley, 2004).

In addition, if the number of remnants increases, distance between them increases and the exposed edge becomes larger (Fahrig, 1997; Sodhi, 2002; Sekercioglu, 2007), resulting as plausible scenario a higher mortality of bird species by high nest predation as well lower food availability near to the edge of remnants with respect to their interior (e.g., Whyte, Didham, \& Briskie, 2005; Newmark \& Stanley, 2011). However, these effects depend 
on the attributes of avian community such as: migratory status, feeding guilds, species richness, and abundance (Stouffer \& Bierregaard, 1995; Bierregaard \& Stouffer, 1997); as well as forest type and the local threats facing each of them. Nevertheless, some bird species are able to use forest remnants surrounded by secondary growth, in a matrix with pasture and crops and other land uses, with stable population sizes and even experiencing significant increases in their populations (Hughes, Daily, \& Ehrlich, 2002; Sekercioglu, Loarie, Oviedo, Ehrlich, \& Daily 2007). Thus, this biodiversity corresponds to species generalists or species associated with anthropogenic activities (Krauss et al., 2010). Forest-interior bird species (i.e., specialist species) abilities to use the matrix of modified habitats surrounding forest fragments may affect their vulnerability in fragmented landscapes i.e. species that avoid the matrix tend to decline or disappear in fragments, while those (i.e., generalist bird species) that tolerate or exploit the matrix often remain stable or increase. However, it is not known what happens in a tourism development where forest remnants are interspersed by residential buildings and tourism activities, which are increasing across the tropical forest in Latin American.

During the period 2000-2010, world tropical forest deforestation was $62 \%$ (Keenan et al., 2015), resulting in 6.5 million hectares lost per year. However, in Mexico showed the largest deforestation rates, with 197651 hectares lost from the 2001 to 2015 period (see details in http://www.globalforestwatch.org/country/ MEX). Tropical forest originally covered about $8 \%$ of the country, being considered a world "hotspot" because of its high biodiversity and endemism (Myers, Mittermeier, Mittermeier, Da Fonseca, \& Kent, 2000). Unfortunately, this ecosystem has experienced high deforestation rates, particularly since the early 1970's, because of conversion to pastures and crops, and the establishment of tourism development. Nonetheless, it is still possible to find considerable amount of tropical forest in the Yucatan Peninsula. However, these tropical forest area consist of forest remnants surrounded by mosaics of agricultural land, tourism development and secondary growth. Therefore, it is very important to know the characteristics and extension of these remnants of tropical forest and evaluate if it possible to conserve bird diversity and richness compared to other areas with different land uses. In order to know if the tropical forest remnants are functioning as bird diversity shelters within a matrix dominated by tourism development in one of the most important tourism area in Mexico, our goal was to better understand differences in bird species richness among natural and modified habitats in Akumal region in Quintana Roo, Mexico. In addition, to investigate the role of the different habitat types in a matrix dominated by tourism development. This study aims to provide a general understanding of how bird communities are affected by tourism development. We expected to find a lower species richness and a distinctive bird species composition in modified environments compared with natural environments (mature tropical forest and tropical forest remnants).

\section{MATERIALS AND METHODS}

Study area: The present study was carried out in Akumal, an area with several tourism developments (covering approximately 143 $\mathrm{km}^{2}$ ) located in the Yucatan Peninsula between $20^{\circ} 30^{\prime} \mathrm{N}-87^{\circ} 12^{\prime} \mathrm{W} \& 20^{\circ} 10^{\prime} \mathrm{N}-87^{\circ} 26^{\prime} \mathrm{W}$ (Fig. 1), at the municipality of Tulum in Quintana Roo, Mexico. This site ranges in elevation from 0 to 20 masl, climate of warm subhumid type with abundant rainfalls in summer. Annual average temperature ranges from 25 to $28{ }^{\circ} \mathrm{C}$, and annual precipitation between 1300 and $1500 \mathrm{~mm}$. Dominant natural vegetation in the area is tropical semideciduous forest, tropical deciduous forest, and tropical flooded forest associated with secondary growth; as well as relicts of dunes coast vegetation and mangrove. Common tree species in the study area included Brosimum alicastrum, Bursera simaruba, Manilkara zapota, Talisia olivaeformis, Metopium brownei, Caesalpinia gaumeri, Thrinax radiata, Coccothrinax readi and 

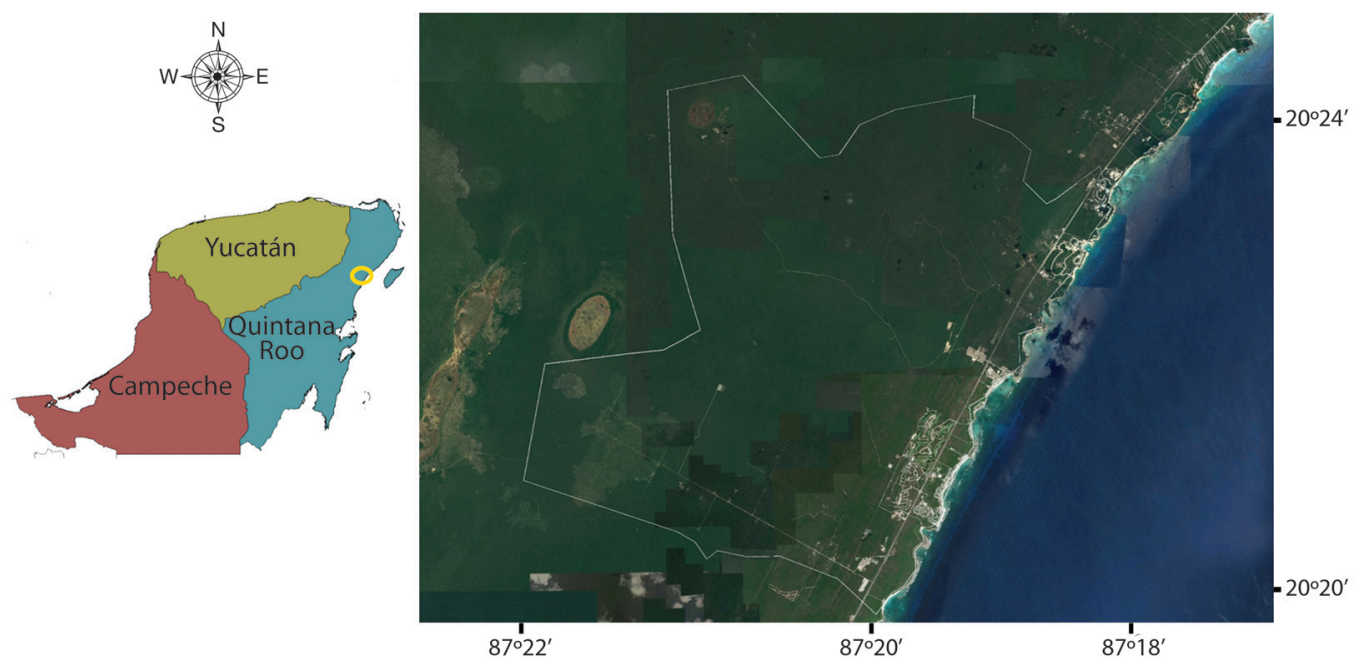

Fig. 1. Map show the location of study area in Yucatan Peninsula, Mexico. The location of study area is found in the eastern Yucatan Peninsula, and it's delimited by a square that it's shown in detail in the right panel.

Pseudophoenix sargentü. The mangrove relicts founded are dominated by Rhizophora mangle and Laguncularia racemose. From the tide line, where the sand accumulates and the soil is very unstable plants, are established Sesuvium portulacastrum, trailblazers like Ambrosia hispida, Salicornia and Hymenocallis littoralis bigelavii. This vegetation is the limit to stable dunes where there is a thicket forming shrub species complex as Cocoloba uvifera, Ipomoea pescaprae, Camavelia rosea, Sophora tomentosa, and Ernodea littoralis, among others (Miranda, 1959; Rzedowski, 1978).

Habitat classification: Habitat classification was based on main vegetation cover, land uses, and the pattern of utilization by settlements as follow: (a) mature tropical forest: tropical semideciduous and tropical deciduous forest $>2$ ha with mature trees $>10$ years with canopy height 8 to $15 \mathrm{~m}$ and, diameters $>20 \mathrm{~cm}$; (b) tropical forest remnants: tropical semideciduous and tropical deciduous forest remnants $<2$ ha with mature trees $<10$ years, with canopy height 4 to $8 \mathrm{~m}$ and, diameters $<20 \mathrm{~cm}$ within golf courses and residential zones; (c) modified environments by tourism developments, that include golf course and artificial water bodies in golf course; hotels zones and residential with natural and introduced vegetation; (e) modified environments by urban developments, crops and livestock, that include urban zone with natural and introduced vegetation, cattle pastures and agricultural fields; (f) coast dunes, beach zone and small remnants mangrove.

Bird surveys: Point counts surveys were conducted along transects in the different habitat types (see above; Hutto, Pletschet, \& Hendricks, 1986) from April 2009 to November 2010, for a total of 412 point counts in 96 days. Points were randomly selected to represent different types of natural vegetation and land uses in the area $\left(107 \mathrm{~km}^{2}\right)$. Distance between sampling points were at least $250 \mathrm{~m}$ to avoid double-counting of highly local species (Hutto et al., 1986; Ralph, Saber, \& Droege, 1995). Observation time by point was $20 \mathrm{~min}$, as proposed for tropical environments (Vielliard, 2000). Points were located in both edge and interior of the forest remnants. Sampling was conducted monthly mostly in the morning (06:00 to $11: 30 \mathrm{~h})$ and in the afternoon (15:30 to $20: 00 \mathrm{~h}$ ), additional to nocturnal observations. Birds were identified by sight and sound (mostly), excluding birds that overflew the 
sampling points. Sampling was avoided on rainy days. Species richness was expressed as the total number of species recorded in each habitat, because effort was approximately equal at all habitats (21 days of sampling effort per habitat, with exception of coast dunes, beach zone and small remnants mangrove, which was 12 days). For species identification, Peterson and Chalif (1989), and Howell and Webb (1995) guides were used, and nomenclature and taxonomic status followed AOU (2017), as well as some supplements.

Bird attributes: Birds were categorized as resident or migratory species according to their presence during the study period and complemented with Howell and Webb (1995). Feeding habits were categorized according to which the species was feeding most frequently, which was complemented with literature sources (Peterson \& Chalif, 1989; Howell \& Webb, 1995) and field observations: omnivores, nectarivores, carnivores, frugivores, granivores, and insectivores (included aquatic invertebrates as well as bark insectivores, aerial insectivores, trunk insectivores, generalist insectivores, ground insectivores, and leaf insectivores). Habitat use preferences were categorized based on Blair (1996), and based on main cover vegetation of the land uses (see above).

Statistical analyses: Species richness was calculated as the cumulative number of species observed in the study area. EstimateS v.9 was used to compute species accumulation curves for the species detected by survey (number of sampling days) (Colwell, 2013). Species accumulation curves estimate the number of species expected in the study area and to compare qualitatively avian richness among habitat types, based on randomized re-sampling from all pooled samples. Asymptote from species accumulation curves was constructed by MichaelisMenton species richness estimation function using EstimateS v.9 (Colwell \& Coddington, 1994). This method estimates of total species richness based on successively larger numbers of samples from the data set. Non-parametric estimator Jackknife 2 was selected based for having the slightest bias in the accuracy data (Walther \& Moore, 2005; Hortal, Borges, \& Gaspar, 2006). The Shannon diversity index $\left(\mathrm{H}^{\prime}\right)$ and Simpson's index $(D)$ were obtained to estimate diversity among habitats (Krebs, 2000). Point Abundance Index (PAI) was calculated by dividing the number of detections for each species by the total number of point's sampled (Blondel, Ferry, \& Frochot, 1970). To understand how community composition differs, and what species are present and how the habitats differ in the mix of species they have, we conducted a hybrid multidimensional scaling ordination (HMDS), using the Bray-Curtis dissimilarity index on untransformed species abundance. The hybrid MDS was introduced by Faith, Michin and Belbin (1987) and combines both the PCoA (principal coordinate analysis or classical MDS) and the non-metric MDS (NMDS). It has the advantage of assuming a linear relationship between the ecological distances obtained by the ordination and the dissimilarity measures where it is most often straight (the PCoA part), and only monotonicity where ecological distances (in the ordination space) are too high to be accurately measured (the NMDS part; Faith et al., 1987). Differences between natural environments and modified environments (see above) were tested using a permutation multivariate analysis of variance (PERMANOVA; Anderson, 2005). Data of the coast dunes, beach zone and mangrove were not included given the low number of sampling points made in those areas. All analyses were conducted using Minitab (see details http:// www.minitab.com/).

\section{RESULTS}

We recorded a total of 1914 bird sightings during the study period, with a bird density of 54.3 individuals/observation-hour. A total of 160 species and 50 families was recorded, from which only five species are considered endemic, and 10 species were most frequently recorded (Appendix). Accumulation curves for sampling by census reached an asymptote 
(Fig. 2A) in the value of 170 species. In this context, Jackknife's 2 estimator resulted in a value of 177 species, indicating that the probability of encountering more species increasing sampling effort is very low (Fig. 2B). From all detected bird species, 99 were permanent residents, 47 were winter visitors, 11 were transients, and three introduced (Appendix). The avian community in the study have a predominance of insectivore species $(\mathrm{N}=97$, see Appendix).

Bird community attributes by habitats: A total of 96 species were found in mature tropical forest, 92 in tropical forest remnants, 79 in modified environments by tourism developments and, 40 in modified environments by urban developments, crops and livestock (Appendix). Accumulation curves showed that the expected species richness present in mature tropical forest had the highest bird richness (Jackknife $2=114$ ), followed by tropical forest remnants with expected species (Jackknife $2=110$ ), modified environments by tourism developments (Jackknife $2=91$ ), and (Jackknife $2=57$; Fig. 2B). Only 17 species were exclusively found in mature tropical forest, three in tropical forest remnants, and the rest
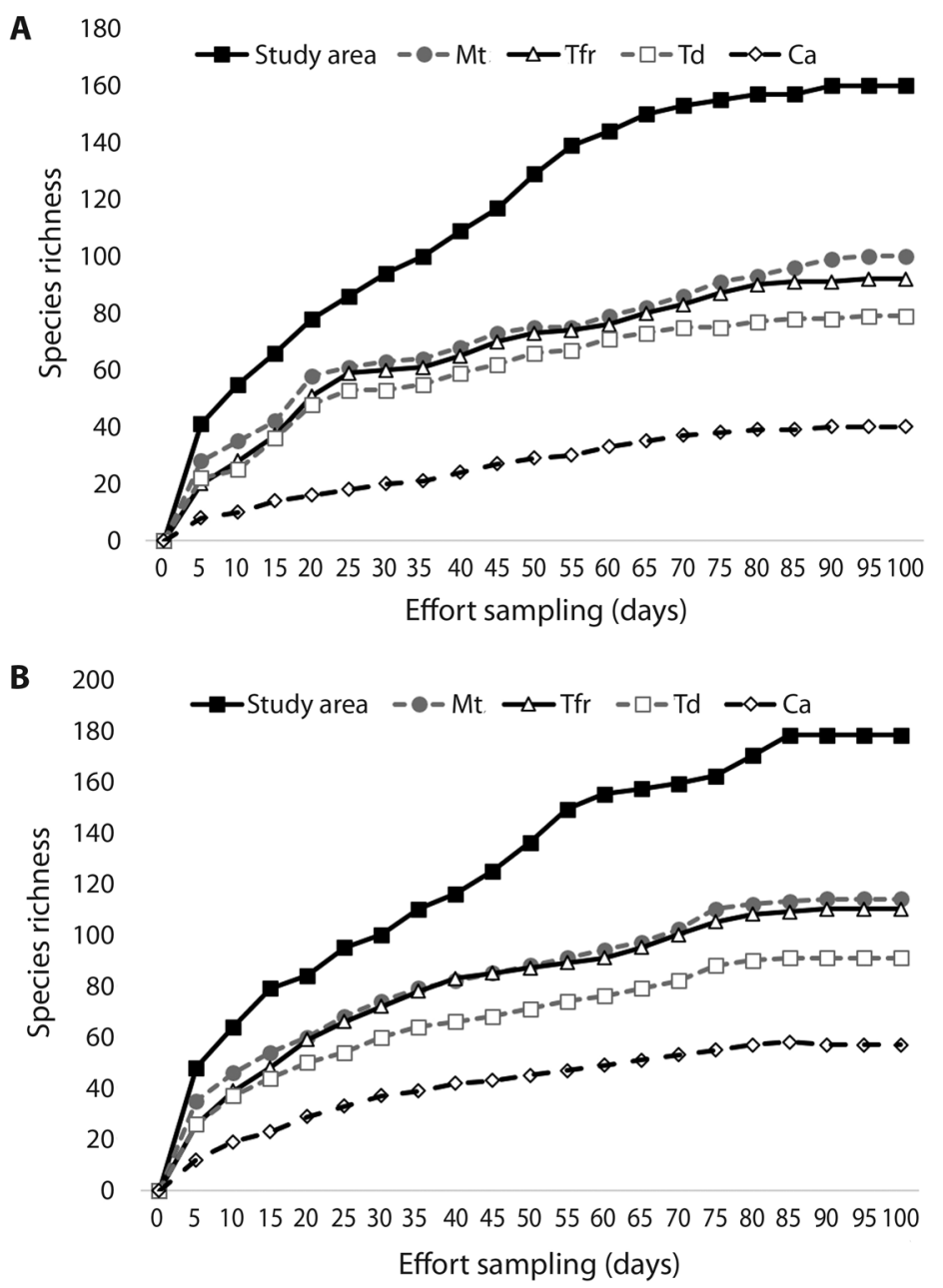

Fig. 2. Species accumulation curve for birds sampled by census in the study area. Observed species richness (a) and expected (b) in the study area and habitat type: Mature tropical forest (Mt), Tropical forest remnants (Tfr), Modified environments by tourism developments (Td), and Modified environments by urban developments, crops and livestock (Ca). 
was shared, and four in modified environments by tourism developments and two in modified environments by urban development, crops and livestock, while the rest were found in two to four habitat types (Appendix). The species richness and diversity values were highest in mature tropical forest (96 species, $\left.\mathrm{H}^{\circ}=3.78 \pm 0.006, \mathrm{D}=0.93 \pm 0.010\right)$ and tropical forest remnants (94 species, $\mathrm{H}^{\circ}=3.32 \pm 0.008$, $\mathrm{D}=0.90 \pm 0.010$ ); while, modified environments by tourism developments $\left(72\right.$ species, $\mathrm{H}^{\star}=$ $2.89 \pm 0.014, \mathrm{D}=0.73 \pm 0.030$ ), and modified environments by urban developments, crops and livestock (40 species, $\mathrm{H}^{\circ}=2.73 \pm 0.012, \mathrm{D}=$ $0.69 \pm 0.029)$ presented the lowest species richness and diversity values (Fig. 3). Bird species richness and diversity values $\left(\mathrm{H}^{\star}, \mathrm{D}\right)$ varied significantly among habitats (Fig. 3; $\mathrm{P}<0.001$ ), with few species detected in modified environments compared with mature tropical forest and tropical forest remnants. This was supported also by the HMDS ordination explained $55 \%$ of the variation in species composition among habitats. Clear gradients in community composition were observed along both axes, with the centroids for mature tropical forest sites and tropical forest remnants having negative values on both axes and the centroids for modified environments (by tourism developments and by urban developments, crops and livestock) having positive values (Fig. 4). Mature tropical forest and tropical forest remnants sites were
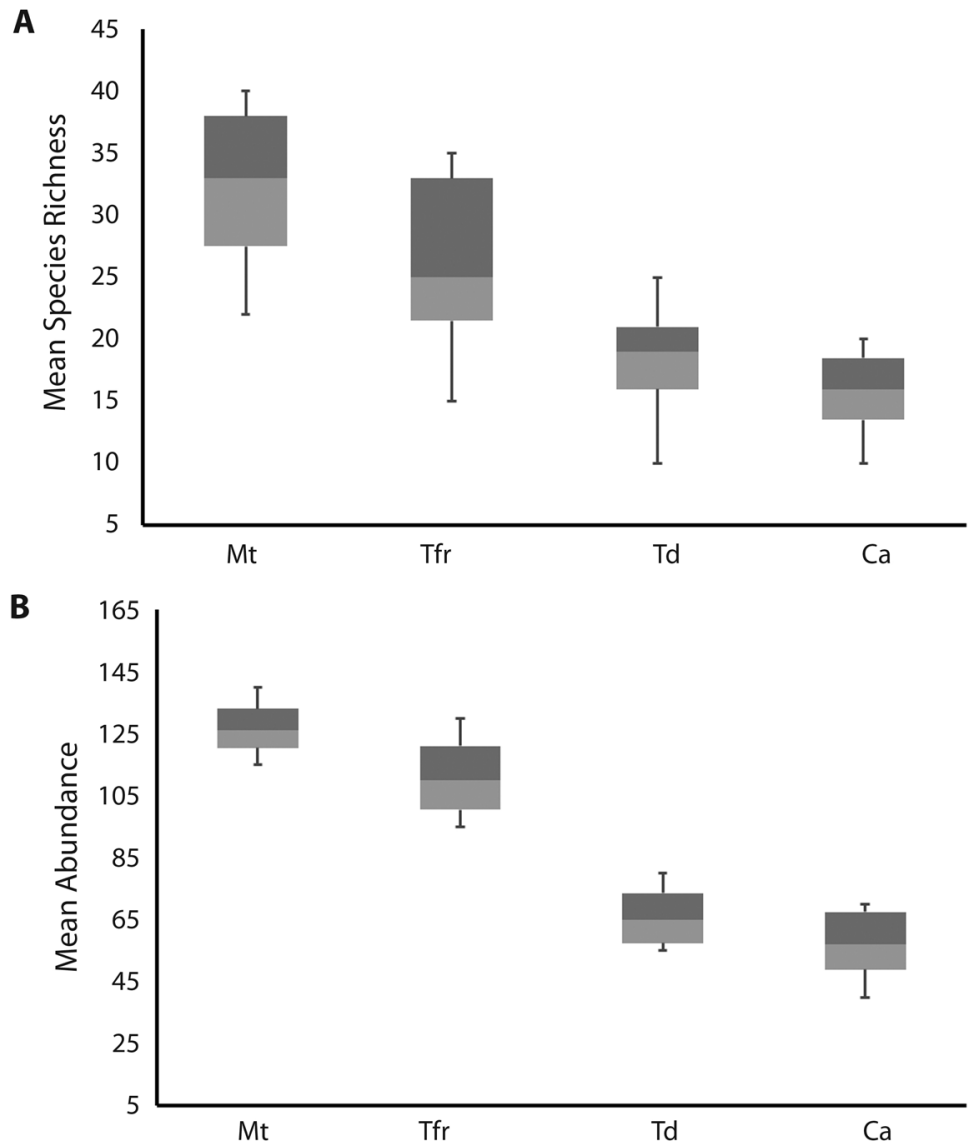

Fig. 3. Boxplots of mean species richness (a), mean abundance (b), (c) Shannon diversity index, and (d) Simpson's diversity index of bird species at Akumal region, Quintana Roo, Mexico: Mature tropical forest (Mt), Tropical forest remnants (Tfr), Modified environments by tourism developments (Td), and Modified environments by urban developments, crops and livestock $(\mathrm{Ca})$. Lines represent minimum, first quartile, median, third quartile, and maximum. 


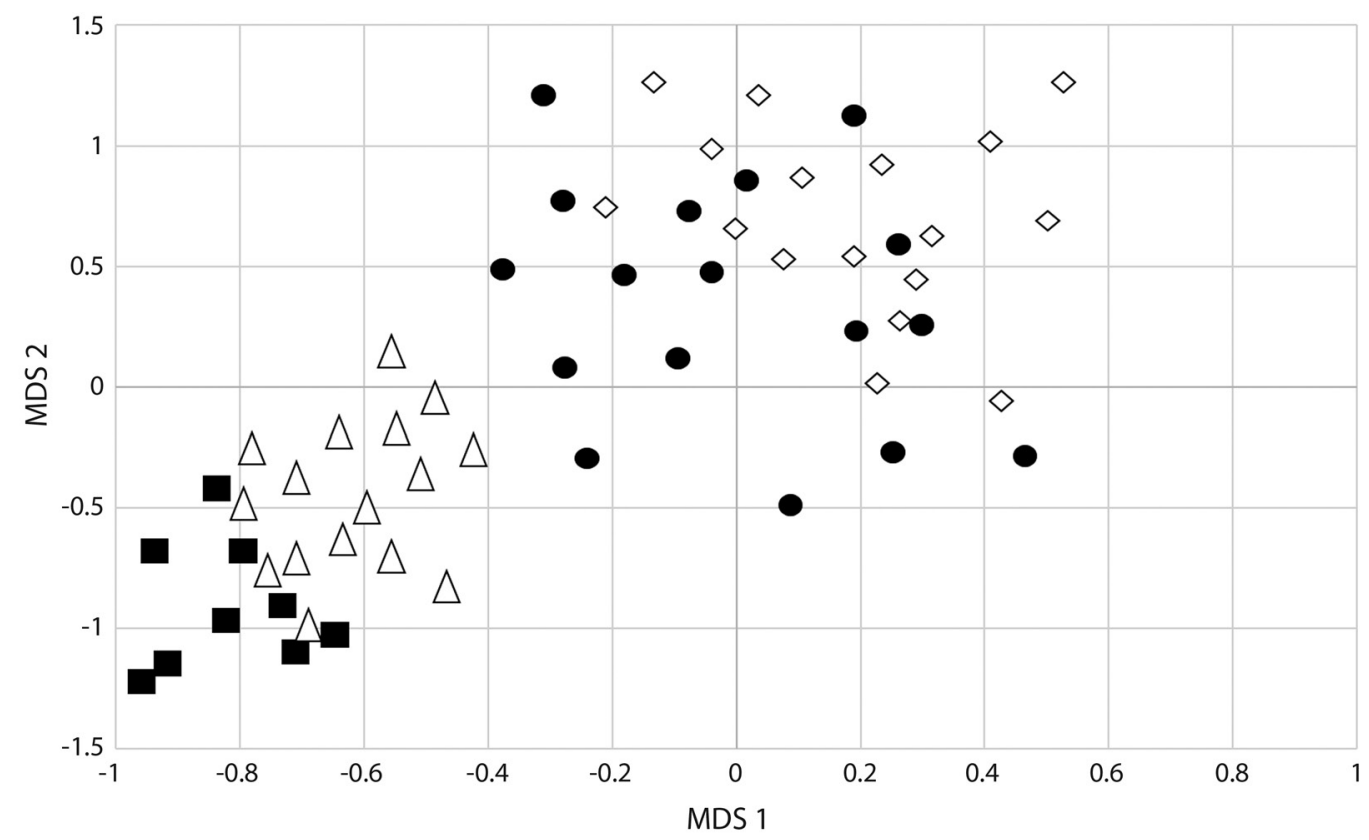

Fig. 4. Ordination plot of HMDS axes showing gradients in bird composition in mature tropical forest ( $\bullet$ ), tropical forest remnants $(\Delta)$, modified environments by tourism developments $(\bullet)$ and modified environments by urban developments, crops and livestock $(\diamond)$.

clearly separated from modified environments, and grouping of same land-use sites was significant $\left(\mathrm{F}_{2}=28.632, \mathrm{R}^{2}=0.412, \mathrm{P}<0.05\right)$ showing that bird richness differ significantly between the four analyzed habitats (Fig. 4). Similarly, with migratory status, the highest species richness of resident and migratory species was recorded in mature tropical forest (69 resident species and 26 migratory species) and tropical forest remnants (62 resident species and 35 migratory species) while modified environments by tourism developments (45 resident species, 26 migratory species, and one introduced species) and modified environments by urban developments, crops and livestock (30 resident species, eight migratory species, and two introduced species) recorded the lowest species richness; but not significant difference depending on migratory status, both migratory and resident species respond the same way. Insectivore species were better represented in the mature tropical forest, and tropical forest remnants $(>16)$. Frugivores and nectarivores species were slightly higher and abundant in mature tropical forest and, tropical forest remnants (with six species in each habitat). Carnivores (18), granivores (10) and omnivores (10) species were better represented in modified environments (particularly in cattle pastures and agricultural fields), and insectivore species were better represented in mature tropical forest (65 species) and, tropical forest remnants (59; Appendix). Results in this study are consistent with respect to that modified environments (i.e., agricultural and livestock areas) had a higher proportion of carnivores and granivores species in comparison with tropical forest.

\section{DISCUSSION}

Our study revealed that mature and tropical forest remnants in Akumal region had higher bird species diversity that the modified environments, which is expected because modified environments lack suitable vegetative 
remnants, shrubs and canopy cover that limits food density and diversity, nest placement, and predator avoidance. Above mentioned reveals the importance of tropical forest remnants for bird diversity conservation in a tourism area, as an important shelters to the bird community. According with our results, Bennet and Saunders (2010) mentioned that the forest remnants are very important in terms of shelter, feeding and nesting areas, particularly to birds that depend on native vegetation.

Bird species recorded accounted for 32 $\%$ of all species reported for Quintana Roo by Correa and MacKinnon (2011), being the order Passeriformes the most representatives with $52 \%$ (83 species) from the total recorded. Abundance index values (PAI) showed a large number of species with low PAI, as well as few species with intermediate to high PAI compared to the pattern observed in other surveys (Aleixo \& Vielliard, 1995; Lyra-Neves, Martins, Mendes, Rodrigues, \& Lacerda, 2004). Bird species richness in the study was similar to other tropical forest areas with a predominance of insectivore species (e.g., Estrada, CoatesEstrada, \& Meritt, 1997; Blake \& Loiselle, 2001). Omnivore species abundance can be directly related to the variety of available resources for change in land use and declining native resources like fruits. However, the presence of frugivore species, also some bark insectivore species indicate that the study area is relatively well conserved (Blake \& Loiselle, 2015). Others signs of relative adequate habitat conditions included the occurrence of mixedspecies flocks (Stotz, Fitzpatrick, Parker, \& Moskovits, 1996), and trunk insectivores. Frequency and structure of mixed-species flocks also suggests habitat conditions at the study area were adequate for many common in tropical forest bird species according to Stotz et al. (1996). Most bird species recorded in this study were dependent on forest edge, these results suggest that the sensitivities of bird species to vegetation are associated with their dependence of food resources as availability of native fruit (Hasiu, Gomes, \& Silva, 2007).
The differences in the species richness and diversity found in this study indicated that the mature tropical forest and tropical forest remnants present greater diversity and richness compared with modified environments. This accords with other studies in tropical environments, and indicates that the loss of original habitats directly influences the presence, abundance and persistence of species (Kattan, Álvarez-López, \& Giraldo, 1994; Laurance \& Bierregaard, 1997; Rocha, Virtanen, \& Cabeza, 2015). The higher avian diversity found in tropical forest may be due to high numbers of individuals and mature vegetation that provide many different microhabitats, which promote varieties of bird species compared with habitats with different land covers (e.g., with human infrastructure or tourism development). However, others studies have found highest richness in modified environments than natural environments (Petit, Petit, Christian, \& Powell, 1999; Martin, Viano, Ratsimisetra, Laloë, \& Carrière, 2012), but this may be due to the environmental heterogeneity that can get to present the area.

Tropical forest remnants had a significant contribution to the bird species richness and diversity in the study area which is consistent with those reported by Estrada et al. (1997) in Los Tuxtlas region in Veracruz, Mexico. On the other hand, bird composition in terms of the feeding guilds is related to vegetation structure (Laurance \& Bierregaard, 1997). Different groups of bird species were found that respond differently to the conversion of forest to modified environments. Not surprisingly, tropical forest assemblages were characterized by a high proportion of forest-associated species, whereas modified habitats were dominated by generalists and open habitat specialists. However, modified environments by urban developments, crops and livestock are very important to a lot of carnivores, granivores and insectivores species because of temporarily or permanently provide such resources depending on their phenology and seasonality (Loiselle \& Blake, 1994).

In general, the tropical forest remnants that presents the study area appears to contribute to 
the relatively high species richness, especially considering the number of species occurring in mature tropical forest. Results of this study showed evidence that tropical forest remnants are significantly important in tourism zones as an available habitat for birds. The continuing expansion of tourism complex, particularly large-scale, will likely result in the simplification and loss of bird diversity. That is particularly important in tourism zones from Quintana Roo because these remnants representing shelters, feeding or nesting areas for birds dependent from natural environments; as well as responsible for maintaining an important proportion of regional avian diversity. The importance of tropical forest remnants provides important habitats for many species of resident and migrant birds in Yucatan Peninsula. Our results confirm the great need for conservation (preserved areas), restoration with native vegetation, and ecological studies of tropical forests remnants, because represent the first step to take actions for conservation of regional avian diversity in the Yucatan Peninsula subjected to anthropogenic activities. An added potential value to this tourist area to attract other tourism type (as birdwatchers) as an alternative to preserve and promote ecological tourism. Furthermore, create incentives for protection and preservation on natural areas and, native biota, which allow preserve these tropical forest remnants.

\section{ACKNOWLEDGMENTS}

Thanks to C. Vázquez and L. del Villar for the help and support in the field work. To Akumal municipally authorities, Villas Jade Beach, Golf and Spa, Naj K'aax Residential, Bahía Principe Residences and Golf, Bahía Principe Hotels and Resorts properties for the facilities during the field work.

\section{RESUMEN}

Remanentes de bosque tropical como refugios de la diversidad de aves dentro de una matriz de desarrollo turístico en la Península de Yucatán, México. Los bosques tropicales han sufrido una transformación extensa debido al aumento de los desarrollos turísticos, además de la compensación histórica de las actividades agrícolas y de pastoreo del ganado. En conjunto, estas actividades han tenido un efecto importante en la diversidad de aves, reduciendo el hábitat disponible para muchas especies. En este estudio, se evaluó el papel de los remanentes de bosque tropical para la diversidad de especies y composición de la comunidad de aves ubicados en diferentes tipos de uso de suelo en la región de Akumal en Quintana Roo, México. Se utilizaron puntos de conteo para caracterizar la avifauna por hábitat, y se utilizó el índice de diversidad de Shannon y Simpson para determinar la diversidad de aves. Además, las especies de aves se clasificaron según la estacionalidad y el gremio alimenticio. Se registraron 160 especies, distribuidas entre 50 familias; 100 especies fueron residentes permanentes, 47 visitantes de invierno y 11 transitorias. El bosque tropical maduro y remanentes de bosque tropical tuvieron una mayor riqueza de especies y valores de diversidad que los ambientes modificados. La composición de las especies de aves de los remanentes de bosque tropical fue similar a la del bosque tropical maduro, pero mayor que los ambientes modificados. Este estudio demuestra la importancia de los remanentes forestales tropicales como refugios y corredores biológicos en paisajes con desarrollos turísticos, y la relevancia de estos remanentes en el mantenimiento de una alta diversidad de aves.

Palabras clave: comunidad de aves; conservación; riqueza de especies; fragmentación; Akumal; Quintana Roo.

\section{REFERENCES}

Aleixo, A., \& Vielliard, J. M. E. (1995). Composição e dinâmica da avifauna da Mata de Santa Genebra, Campinas, São Paulo, Brasil. Revista Brasileira de Zoologia, 12, 493-511.

Anderson, M. (2005). PERMANOVA: a fortran Computer Program for Permutational Multivariate Analysis of Variance. Auckland: Department of Statistics, University of Auckland.

AOU (American Ornithologists' Union). 2017. Checklist of North American birds. American Ornithologists' Union. Available at http://checklist.aou.org

Bennet, A. F., \& Saunders, D. A. (2010). Habitat fragmentation and landscape change. In N. S. Sodhi \& P. R. Ehrlich (Eds.), Conservation Biology for All (pp. 88-106). NY: Oxford University Press.

Bierregaard Jr., R. O., \& Stouffer, P. C. (1997). Understory birds and dynamic habitat mosaics in Amazonian rainforest. In W. F. Laurance \& Jr., R. O. Bierregaard (Eds.), Tropical Forest Remnants: Ecology, Management, and Conservation of Fragmented (pp. 138155). Chicago: University of Chicago Press. 
Blair, R. B. (1996). Land use and avian species diversity along an urban gradient. Ecological Applications, 6, 506-519.

Blake, J. G., \& Loiselle, B. A. (2001). Bird assemblages in second-growth and old-growth forest, Costa Rica: perspectives from mist nest and point counts. Auk, $118,304-326$.

Blake, J. G., \& Loiselle, B. A. (2015). Enigmatic declines in bird numbers in lowland forest of eastern Ecuador may be a consequence of climate change. Peer Journal, 3, e1177.

Blondel, J., Ferry, C., \& Frochot, B. (1970). La méthode des indices ponctuels d'abondance (I.P.A.) ou des relevés d'avifaune par „stations d'écoute“. Alauda, $38,55-71$.

Buckley, R. (2004). Impacts of ecotourism on birds. In R Buckley (Ed.), Environmental impacts of ecotourism (pp. 187-210). Cambridge: CAB International.

Chettri, N., Chandra, D., Sharma, E., \& Jackson, R. (2005) The relationship between bird communities and habitat. A study along a trekking corridor in the Sikkim Himalaya. Mountain Research and Development Journal, 25, 235-243.

Christ, C., Hillel, O., Matus, S., \& Sweeting, J. (2003). Tourism and biodiversity: mapping tourism's global footprint. Washington, D.C.: Conservation International \& United Nations Environment Programme.

Colwell, R. K. (2013). EstimateS v.9. Available at http:// viceroy.eeb.uconn.edu/estimates

Colwell, R. K., \& Coddington, J. A. (1994). Estimating terrestrial biodiversity through extrapolation. Philosophical Transactions of the Royal Society of London B, 345, 101-118.

Correa, J., \& MacKinnon, B. (2011). Aves. In C. Pozo (Ed.), Riqueza biológica de Quintana Roo. Un análisis para su conservación Tomo 2 (pp. 252-266). Chetumal, México: El Colegio de la Frontera SurCONABIO-Gobierno del Estado de Quintana RooPrograma de Pequeñas Donaciones.

Estrada, A., Coates-Estrada, R., \& Meritt, D. A. (1997). Anthropogenic landscape changes and avian diversity at Los Tuxtlas, Mexico. Biodiversity and Conservation, 6, 19-43.

Fahrig, L. (1997). Relative effects of habitat loss and fragmentation on population extinction. Journal of Wildlife Management, 61, 603-610.

Faith, D. P., Michin, P. R., \& Belbin, L. (1987). Compositional dissimilarity as a robust measure of ecological distance. Vegetatio, 69, 57-68

Hasui, E., Gomes, V. S. M., \& Silva, W. R. (2007). Effects of vegetation traits on habitat preferences of frugivorous birds in Atlantic rainforest. Biotropica, 39, 502-509.

Hortal, J., Borges, P. A. V., \& Gaspar, C. (2006). Evaluating the performance of species richness estimators: sensitivity to sample grain size. Journal of Animal Ecology, 75, 274-287.

Howell, S., \& Webb, S. (1995). A guide to the birds of Mexico and northern Central America. New York: Oxford University Press.

Hughes, J. B., Daily, G. C., \& Ehrlich, P. R. (2002) Conservation of tropical forest birds in countryside habitats. Ecology Letters, 5, 121-129.

Hutto, R. L., Pletschet, S. M., \& Hendricks, P. (1986). A fixed-radius point count method for non-breeding and breeding season use. Auk, 103, 593-602.

Kattan, G. H., Álvarez-López, H., \& Giraldo, M. (1994). Forest fragmentation and bird extinction: San Antonio eighty years later. Conservation Biology, 8 , 138-146.

Keenan, R. J., Reams, G., Achards, F., De Freitas, J., Grainger, A., \& Lindquist, E. (2015). Dynamics of global forest area: results from the FAO Global Forest Resources Assessment 2015. Forest Ecology and Management, 352, 9-20.

Krauss, J., Bommarco, R., Guardiola, M., Heikkinen, R. K., Helm, A., Kuussaari, M., ... \& Steffan-Derenter, I. (2010). Habitat fragmentation causes immediate and time delayed biodiversity loss at different trophic levels. Ecology Letters, 13, 597-605.

Krebs, C. J. (2000). Ecología: estudio de la distribución y la abundancia (2a . ed.). México: Oxford University Press.

Lambin, E. F., Geist, H. J., \& Lepers, E. (2003). Dynamics of land-use and land-cover change in tropical regions. Annual Review of Ecology, Evolution, and Systematics, 28, 205-241.

Laurance, W. F., \& Bierregaard, Jr., R. O. (1997). Tropical forest remnants: ecology, management, and conservation of fragmented communities. Chicago: University of Chicago Press.

Loiselle, B., \& Blake, J. G. (1994). Annual variation in birds and plants of a tropical second-growth woodland. Condor, 96, 368-380.

Lyra-Neves, R. M., Martins, M., Mendes, S., Rodrigues, W., \& Lacerda, M. E. (2004). Comunidade de aves da Reserva Estadual de Gurjaú, Pernambuco, Brasil. Revista Brasileira de Zoologia, 21, 581-592.

Martin, E. A., Viano, M., Ratsimisetra, L., Laloë, F., \& Carrière, S. M. (2012). Maintenance of bird functional diversity in a traditional agroecosystem 
of Madagascar. Agriculture, Ecosystems \& Environment, 149, 1-9.

McGarigal, K., \& McComb, W. C. (1995). Relationships between landscape structure and breeding birds in the Oregon coast range. Ecological Monographs, 65, 235-260.

Miranda, F. (1959). La vegetación de la península yucateca en los recursos naturales del sureste y su aprovechamiento II parte: estudios particulares. México: IMRNR.

Myers, N., Mittermeier, R. A., Mittermeier, C. G., Da Fonseca, G. A. B., \& Kent, J. (2000). Biodiversity hotspots for conservation priorities. Nature, 403, 853-858.

Newmark, W. D., \& Stanley, T. R. (2011). Habitat fragmentation reduces nest survival in an Afrotropical bird community in a biodiversity hotspot. Proceedings of the National Academy of Sciences USA, 108, 11488-11493.

Newsome, D., Moore, S. A., \& Dowling, R. K. (2002). Natural area tourism: ecology, impacts and management. Sydney: Channel View Publications.

Peterson, R. T., \& Chalif, E. L. (1989). Aves de México. Guía de campo. México: Ed. Diana.

Petit, L. J., Petit, D. R., Christian, D. G., \& Powell, H. D. W. (1999). Bird communities of natural and modified habitats in Panama. Ecography, 22, 292-304.

Ralph, C. J., Saber, J. R., \& Droege, S. (1995). Monitoring bird populations by point counts. General Technical Report PSW-GTR-149. Albany, CA: USDA Forest Service, Pacific Southwest Research Station.

Rocha, R., Virtanen, T., \& Cabeza, M. (2015). Bird assemblages in a Malagasy forest-agricultural frontier: effects of habitat structure and forest cover. Tropical Conservation Science, 8, 681-710.

Rzedowski, J. (1978). Vegetación de México. México: Edit. Limusa.
Schlaepfer, M. A., Sax, D. F., \& Olden, J. D. (2011). The potential conservation value of non-native species. Conservation Biology, 25, 428-437.

Sekercioglu, C. H. (2007). Conservation ecology: area trumps mobility in fragment bird extinctions. Current Biology, 17, 283-286.

Sekercioglu, C. H., Loarie, S., Oviedo, F., Ehrlich, P. R., \& Daily, G. C. (2007). Persistence of forest birds in the Costa Rican agricultural countryside. Conservation Biology, 21, 482-494.

Sodhi, N. S. (2002). A comparison of bird communities of two fragmented and two continuous Southeast Asian rainforests. Biodiversity and Conservation, 11, 1105-1119.

Stotz, D. F., Fitzpatrick, J. W., Parker III, T. A., \& Moskovits, D. K. (1996). Neotropical birds: ecology and conservation. Chicago: University of Chicago Press.

Stouffer, P., \& Bierregaard Jr., R. O. (1995). Use of Amazonian forest fragments by understory insectivorous birds. Ecology, 76, 2429-2445.

Vielliard, J. M. E. (2000). Bird community as an indicator of biodiversity: results from quantitative surveys in Brazil. Anais da Academia Brasileira de Ciências, 72, 323-330.

Walther, B. A., \& Moore, J. L. (2005). The concepts of bias, precision and accuracy, and their use in testing the performances of species richness estimators, with a literature review of estimator performance. Ecography, 28, 815-829.

White, R. L., Baptiste, T. J. N., Dornelly, A., Morton, M. N., O'Connell, M. J., \& Young, R. P. (2012). Population responses of the endangered White-breasted Thrasher Ramphocinclus brachyurus to a tourist development in Saint Lucia-conservation implications from a spatial modeling approach. Bird Conservation International, 22, 468-485.

Whyte, B. I., Didham, R. K., \& Briskie, J. V. (2005). The effect of forest edge and nest height on nest predation in two differing New Zealand forest habitats. New Zealand Natural Sciences, 30, 19-34. 


\section{APPENDIX}

Bird species recorded were classified according to their migratory status and feeding habits in each habitat type in Akumal region, Quintana Roo, Mexico

\begin{tabular}{|c|c|c|c|c|}
\hline Species & Migratory status & Feeding habits* & PAI & Habitat use preferences** \\
\hline Dendrocygna autumnalis & Resident & I & 0.9856 & Td $(\mathrm{Gc})$ \\
\hline Anas discors & Winter visitor & I & 0.6312 & Td $(\mathrm{Gc})$ \\
\hline Nomonyx dominicus & Resident & I & 0.9856 & Td $(\mathrm{Gc})$ \\
\hline Ortalis vetula & Resident & $\mathrm{Fr}$ & 1.8874 & Td (Gc), Cbm \\
\hline Phoenicopterus ruber & Resident & $\mathrm{I}$ & 0.1322 & Cbm \\
\hline Podilymbus podiceps & Winter visitor & I & 0.6312 & Td (Gc), Cbm \\
\hline Columba livia & Introduced & $\mathrm{Om}$ & 2.2480 & Ca (Us) \\
\hline Patagioenas flavirostris & Resident & $\mathrm{Fr}$ & 0.8523 & Mt \\
\hline Streptopelia decaocto & Introduced & $\mathrm{Om}$ & 0.8523 & Td (Rh), Ca (Us) \\
\hline Columbina passerina & Resident & $\mathrm{Gr}$ & 1.2340 & Tfr, Td (Rh) \\
\hline Zenaida asiatica & Resident & $\mathrm{Gr}$ & 1.2340 & Mt, Tfr, Td (Gc, Rh), Ca (Cp, Us) \\
\hline Zenaida aurita & Resident & $\mathrm{Gr}$ & 1.2003 & Td $(\mathrm{Rh}), \mathbf{C a}(\mathrm{Cp}, \mathrm{Us})$ \\
\hline Coccyzus minor & Resident & Fr, I & 0.0045 & Mt, Tfr \\
\hline Chordeiles acutipennis & Resident & I & 0.0987 & Mt, Tfr, Td (Gc) \\
\hline Nyctidromus albicollis & Resident & I & 0.0846 & Mt \\
\hline Chaetura vauxi & Resident & $\mathrm{I}$ & 1.0084 & Mt, Tfr, Td (Gc, Rh), Ca (Cp, Us) \\
\hline Anthracothorax prevostii & Resident & $\mathrm{Ne}$ & 0.0012 & Mt \\
\hline Archilochus colubris & Winter visitor & $\mathrm{Ne}$ & 0.0458 & Mt, Tfr \\
\hline Chlorostilbon canivetii & Resident & $\mathrm{Ne}$ & 0.0683 & Mt, Tfr \\
\hline Amazilia yucatanensis & Resident & $\mathrm{Ne}$ & 0.0879 & Mt, Tfr \\
\hline Amazilia rutila & Resident & $\mathrm{Ne}$ & 0.0879 & Mt, Tfr, Td (Rh), Ca (Us) \\
\hline Gallinula chloropus & Winter visitor & $\mathrm{I}$ & 0.0875 & $\mathbf{T d}(\mathrm{Gc}), \mathbf{C b m}$ \\
\hline Fulica americana & Winter visitor & I & 0.0875 & Td (Gc), Cbm \\
\hline Himantopus mexicanus & Transient & I & 0.0987 & Td $(\mathrm{Gc})$ \\
\hline Pluvialis squatorola & Winter visitor & I & 0.0784 & Cbm \\
\hline Pluvialis dominica & Transient & I & 0.0012 & Td $(\mathrm{Gc}), \mathbf{C b m}$ \\
\hline Charadrius semipalmatus & Winter visitor & I & 0.5489 & Cbm \\
\hline Charadrius vociferus & Winter visitor & I & 0.6231 & Td (Gc), Cbm \\
\hline Jacana spinosa & Resident & I & 0.0023 & Td (Gc), Cbm \\
\hline Actitis macularius & Winter visitor & I & 0.0987 & Td (Gc), Cbm \\
\hline Tringa solitaria & Winter visitor & I & 0.0846 & Td (Gc), Cbm \\
\hline Arenaria interpres & Winter visitor & I & 0.0846 & Cbm \\
\hline Calidris minutilla & Winter visitor & I & 0.0846 & Cbm \\
\hline Calidris pusilla & Transient & $\mathrm{I}$ & 0.0784 & Cbm \\
\hline Leucophaeus atricilla & Winter visitor & $\mathrm{Ca}$ & 0.0784 & Cbm \\
\hline Hydroprogne caspia & Winter visitor & $\mathrm{Ca}$ & 0.0458 & Cbm \\
\hline Chlidonias niger & Transient & $\mathrm{I}, \mathrm{Ca}$ & 0.0030 & Cbm \\
\hline Thalasseus elegans & Winter visitor & $\mathrm{Ca}$ & 0.0458 & Cbm \\
\hline Thalasseus maximus & Winter visitor & $\mathrm{Ca}$ & 0.0458 & Cbm \\
\hline Fregata magnificens & Resident & $\mathrm{Ca}$ & 0.6307 & Td (Gc), Cbm \\
\hline Sula leucogaster & Resident & $\mathrm{Ca}$ & 0.5543 & Td (Gc), Cbm \\
\hline Phalacrocorax brasilianus & Resident & $\mathrm{Ca}$ & 0.9936 & Td (Gc), Cbm \\
\hline Anhinga anhinga & Resident & $\mathrm{Ca}$ & 0.9701 & Td (Gc), Cbm \\
\hline Pelecanus occidentalis & Resident & $\mathrm{Ca}$ & 0.6111 & Td (Gc), Cbm \\
\hline Ardea herodias & Winter visitor & $\mathrm{Ca}$ & 0.0224 & Td (Gc), Cbm \\
\hline
\end{tabular}




\begin{tabular}{|c|c|c|c|c|}
\hline Species & Migratory status & Feeding habits* & PAI & Habitat use preferences** \\
\hline Ardea alba & Resident & $\mathrm{Ca}$ & 0.0458 & Td $(\mathrm{Gc}), \mathbf{C b m}$ \\
\hline Egretta thula & Resident & $\mathrm{I}, \mathrm{Ca}$ & 0.1322 & Td (Gc), Cbm \\
\hline Egretta caerulea & Winter visitor & $\mathrm{I}, \mathrm{Ca}$ & 0.1322 & Td (Gc), Cbm \\
\hline Egretta tricolor & Winter visitor & $\mathrm{I}, \mathrm{Ca}$ & 0.0112 & Td (Gc), Cbm \\
\hline Bubulcus ibis & Resident & I & 0.7789 & $\mathbf{C a}(\mathrm{Cp})$ \\
\hline Butorides virescens & Resident & $\mathrm{I}, \mathrm{Ca}$ & 0.0112 & Td (Gc), Cbm \\
\hline Euducimus albus & Resident & I & 0.6803 & Td (Gc), Cbm \\
\hline Coragyps atratus & Resident & $\mathrm{Ca}$ & 1.9635 & Mt, Tfr, Td (Gc, Rh), Ca (Cp, Us) \\
\hline Cathartes aura & Resident & $\mathrm{Ca}$ & 1.9648 & Mt, Tfr, Td (Gc, Rh), Ca (Cp, Us) \\
\hline Pandion haliaetus & Winter visitor & $\mathrm{Ca}$ & 0.0112 & $\mathrm{Cbm}$ \\
\hline Buteogallus anthracinus & Resident & $\mathrm{Ca}$ & 0.0157 & Tfr, Cbm \\
\hline Rupornis magnirostris & Resident & $\mathrm{Ca}$ & 0.1002 & Mt, Tfr, Ca (Cp, Us) \\
\hline Buteo nitidus & Resident & $\mathrm{Ca}$ & 0.0875 & Mt, Tfr, Ca (Cp) \\
\hline Tyto alba & Resident & $\mathrm{Ca}$ & 0.0045 & $\mathbf{T d}(\mathrm{Rh}), \mathbf{C a}(\mathrm{Cp}, \mathrm{Us})$ \\
\hline Megascops guatemalae & Resident & $\mathrm{Ca}$ & 0.0012 & Mt, Tfr \\
\hline Glaucidium brasilianum & Resident & $\mathrm{Ca}$ & 0.0012 & Mt \\
\hline Trogon melanocephalus & Resident & $\mathrm{Fr}$ & 0.0085 & Mt, Tfr \\
\hline Trogon caligatus & Resident & $\mathrm{Fr}$ & 0.0088 & Mt, \\
\hline Momotus coeruliceps & Resident & $\mathrm{Om}$ & 0.0654 & Mt \\
\hline Eumomota superciliosa & Resident & $\mathrm{Om}$ & 0.0879 & Mt, Tfr \\
\hline Megaceryle alcyon & Winter visitor & $\mathrm{Ca}$ & 0.0085 & Td (Gc), Cbm \\
\hline Chloroceryle americana & Resident & $\mathrm{Ca}$ & 0.0084 & Td (Gc), Cbm \\
\hline Melanerpes pygmaeus & Resident & I & 0.0879 & Mt, Tfr \\
\hline Melanerpes aurifrons & Resident & I & 0.6321 & Mt, Tfr, Td (Rh), Ca (Us) \\
\hline Picoides scalaris & Resident & I & 0.6004 & Tfr, Td (Rh), Ca (Us) \\
\hline Campephilus guatemalensis & Resident & I & 0.0081 & Mt, Tfr \\
\hline Herpetotheres cachinans & Resident & $\mathrm{Ca}$ & 0.0879 & $\mathbf{T f r}, \mathbf{C a}(\mathrm{Cp})$ \\
\hline Falco sparverius & Winter visitor & $\mathrm{Ca}$ & 0.0701 & $\mathbf{T f r}, \mathbf{C a}(\mathrm{Cp})$ \\
\hline Falco columbarius & Winter visitor & $\mathrm{Ca}$ & 0.0556 & Mt, Tfr, Td (Gc), Ca (Cp) \\
\hline Eupsittula nana & Resident & Fr & 0.7540 & Mt, Tfr, Td (Rh), Ca (Cp, Us) \\
\hline Amazona xantholora & Resident & Fr & 0.6412 & Mt \\
\hline Sittasomus griseicapillus & Resident & I & 0.0683 & Mt \\
\hline Xiphorhynchus flavigaster & Resident & I & 0.0023 & Mt \\
\hline Synallaxis erythrothorax & Resident & I & 0.0023 & Mt \\
\hline Camptostoma imberbe & Resident & I & 0.0023 & Mt, Tfr \\
\hline Myiopagis viridicata & Resident & I & 0.0245 & Mt, Tfr \\
\hline Elaenia flavogaster & Resident & I & 0.0023 & Mt, Tfr \\
\hline Oncostoma cinereigulare & Resident & I & 0.0245 & Mt \\
\hline Todirostrum cinereum & Resident & I & 0.0023 & Mt \\
\hline Rhynchocyclus brevirostris & Resident & I & 0.0023 & Mt \\
\hline Contopus virens & Transient & I & 0.0245 & Mt, Tfr \\
\hline Contopus cinereus & Resident & I & 0.0335 & Mt, Tfr, Td (Rh), Ca (Cp) \\
\hline Attila spadiceus & Resident & I & 0.0335 & Mt, Tfr \\
\hline Myiarchus yucatanensis & Resident & I & 0.0335 & Tfr \\
\hline Myiarchus tuberculifer & Resident & I & 0.0278 & Mt, Tfr, Td (Rh), Ca (Cp, Us) \\
\hline Myiarchus tyrannulus & Resident & I & 0.1150 & Mt, Tfr, Td (Rh), Ca (Cp, Us) \\
\hline Pitangus sulphuratus & Resident & $\mathrm{Om}$ & 0.2369 & Mt, Tfr, Td (Rh, Gc), Ca (Us) \\
\hline Myiozetetes similis & Resident & I & 0.4481 & Mt, Tfr, Td (Rh), Ca (Us) \\
\hline Myiodynastes luteiventris & Resident & I & 0.1150 & Mt, Tfr \\
\hline
\end{tabular}




\begin{tabular}{|c|c|c|c|c|}
\hline Species & Migratory status & Feeding habits* & PAI & Habitat use preferences** \\
\hline Tyrannus melancholicus & Resident & I & 0.2369 & Tfr, Td (Gc, Rh), Ca (Cp, Us) \\
\hline Tyrannus couchii & Resident & I & 0.2369 & Mt, Tfr, Td (Gc), Ca (Cp) \\
\hline Tyrannus tyrannus & Transient & I & 0.1150 & Mt, Tfr, Td (Rh), Ca (Cp) \\
\hline Tityra semifasciata & Resident & Fr, I & 0.2369 & Mt, Tfr \\
\hline Pachyramphus aglaiae & Resident & I & 0.1123 & Mt, Tfr \\
\hline Vireo pallens & Resident & I & 0.2369 & Mt \\
\hline Vireo philadelphicus & Winter visitor & I & 0.2369 & Mt, Tfr \\
\hline Vireo magister & Resident & I & 0.1123 & Mt \\
\hline Psilorhinus morio & Resident & $\mathrm{Om}$ & 1.0523 & Mt, Tfr, Td (Rh), Ca(Cp) \\
\hline Cyanocorax yucatanicus & Resident & $\mathrm{Om}$ & 1.1238 & Mt, Tfr, Td (Rh) \\
\hline Stelgidopteryx serripennis & Winter visitor & I & 1.0523 & Mt, Tfr, Td (Gc, Rh), Ca (Cp, Us) \\
\hline Riparia riparia & Transient & I & 1.0035 & Td $(\mathrm{Gc}), \mathbf{C b m}$ \\
\hline Petrochelidon fulva & Resident & I & 1.0523 & Td (Gc), Cbm, Ca (Cp) \\
\hline Hirundo rustica & Transient & I & 1.0035 & Td (Rh, Gc), Ca (Cp, Us) \\
\hline Thryothorus maculipectus & Resident & I & 0.1123 & Mt, Tfr \\
\hline Thryothorus ludovicianus & Resident & I & 0.1122 & Mt, Tfr \\
\hline Uropsila leucogastra & Resident & I & 0.2369 & Mt, Tfr \\
\hline Polioptila caerulea & Resident & I & 0.2035 & Mt, Tfr, Td (Rh), Ca (Us) \\
\hline Catharus ustulatus & Transient & I & 0.1122 & Mt, Tfr \\
\hline Turdus grayi & Resident & $\mathrm{Om}$ & 0.2369 & Mt, Tfr, Td (Rh) \\
\hline Hylocichla mustelina & Winter visitor & I & 0.1122 & Mt, Tfr \\
\hline Dumetella carolinensis & Resident & I & 0.2369 & Mt, Tfr \\
\hline Melanoptila glabirostris & Resident & I & 0.1123 & Mt, Tfr \\
\hline Mimus gilvus & Resident & Fr, I & 0.2369 & Mt, Tfr, Td (Rh), Ca (Us) \\
\hline Arremonops rufivirgatus & Resident & $\mathrm{Gr}$ & 0.1123 & Mt, Tfr \\
\hline Euphonia hirundinacea & Resident & $\mathrm{Fr}$ & 0.2369 & Mt \\
\hline Dives dives & Resident & $\mathrm{Om}$ & 0.9856 & Mt, Tfr, Td (Gc, Rh), Ca (Us) \\
\hline Quiscalus mexicanus & Resident & $\mathrm{Om}$ & 3.4522 & Td (Gc, Rh), Ca (Us) \\
\hline Molothrus aeneus & Resident & Gr & 0.9856 & Td (Gc, Rh), Ca (Us) \\
\hline Icterus prosthemelas & Resident & I & 0.2369 & Mt, Tfr \\
\hline Icterus cucullatus & Resident & Om & 0.2568 & Mt, Tfr, Td (Rh) \\
\hline Icterus chrysater & Resident & I & 0.1148 & Mt, Tfr \\
\hline Icterus auratus & Resident & I & 0.1148 & Mt, Tfr \\
\hline Icterus galbula & Winter visitor & Om & 0.1148 & Tfr, Td (Rh) \\
\hline Seiurus aurocapilla & Winter visitor & I & 0.1123 & Mt, Tfr \\
\hline Helmitheros vermivorum & Winter visitor & I & 0.1123 & Mt, Tfr \\
\hline Parkesia noveboracensis & Winter visitor & I & 1.0035 & Mt, Tfr \\
\hline Mniotilta varia & Winter visitor & I & 0.1123 & Mt, Tfr, Td (Rh) \\
\hline Protonotaria citrea & Transient & I & 0.0041 & Mt, Tfr \\
\hline Oreothlypis peregrina & Transient & I & 0.0041 & Mt, Tfr \\
\hline Oreothlypis ruficapilla & Winter visitor & I & 0.1148 & Mt, Tfr, Td (Rh) \\
\hline Geothlypis poliocephala & Resident & I & 0.0245 & Mt, Tfr \\
\hline Geothlypis trichas & Winter visitor & I & 0.0041 & Tfr \\
\hline Setophaga citrina & Winter visitor & I & 0.0041 & Mt, Tfr \\
\hline Setophaga ruticilla & Winter visitor & I & 0.0041 & Mt, Tfr \\
\hline Setophaga americana & Winter visitor & I & 0.0041 & Mt, Tfr \\
\hline Setophaga magnolia & Winter visitor & I & 0.1123 & Mt, Tfr \\
\hline Setophaga petechia & Winter visitor & I & 0.1148 & Mt, Tfr, Td (Rh) \\
\hline Setophaga caerulescens & Winter visitor & I & 0.0041 & Mt, Tfr \\
\hline
\end{tabular}




\begin{tabular}{|c|c|c|c|c|}
\hline Species & Migratory status & Feeding habits* & PAI & Habitat use preferences** \\
\hline Setophaga virens & Winter visitor & I & 0.0041 & Mt, Tfr \\
\hline Cardellina canadensis & Winter visitor & I & 0.0041 & Mt, Tfr \\
\hline Cardellina pusilla & Winter visitor & I & 0.0245 & Tfr, Td (Rh), Ca (Us) \\
\hline Icteria virens & Winter visitor & I & 0.0041 & Mt, Tfr, Td (Rh) \\
\hline Thraupis abbas & Resident & Fr, I & 0.1148 & Mt, Tfr \\
\hline Piranga roseogularis & Resident & I & 0.2035 & Mt \\
\hline Piranga rubra & Winter visitor & I & 0.2369 & Mt, Tfr \\
\hline Cardinalis cardinalis & Resident & $\mathrm{Gr}$ & 0.1148 & Tfr \\
\hline Pheucticus ludovicianus & Winter visitor & $\mathrm{I}, \mathrm{Gr}$ & 0.2035 & Mt, Tfr, Td (Rh) \\
\hline Cyanocompsa parellina & Resident & $\mathrm{Gr}$ & 0.2369 & Mt, Tfr, Td (Rh) \\
\hline Passerina caerulea & Winter visitor & $\mathrm{Gr}$ & 0.2568 & Tfr, Td (Rh), Ca (Us, Cp) \\
\hline Passerina cyanea & Winter visitor & $\mathrm{Gr}$ & 0.1148 & Tfr, Ca $(\mathrm{Cp})$ \\
\hline Volatinia jacarina & Resident & $\mathrm{Gr}$ & 0.1123 & Tfr, Ca (Cp) \\
\hline Cyanerpes cyaneus & Resident & $\mathrm{Ne}$ & 0.1123 & Mt, Tfr \\
\hline Sporophila torqueola & Resident & $\mathrm{Gr}$ & 0.1148 & Tfr, Ca (Cp) \\
\hline Saltator atriceps & Resident & $\mathrm{Gr}$ & 0.2035 & Mt, Tfr \\
\hline Saltator coerulescens & Resident & $\mathrm{Gr}$ & 0.2369 & Mt, Tfr \\
\hline
\end{tabular}

* Feeding habits: Omnivores (Om); Nectarivores (Ne); Carnivores (Ca); Frugivores (Fr); Granivores (Gr); Invertebrates (I, included aquatic invertebrates, bark insectivores aerial insectivores, trunk insectivores, generalist insectivores, ground insectivores, and leaf insectivores.

** Habitat use preferences: Mature tropical forest (Mt); Tropical forest remnants (Tfr), Modified environments by tourism developments (Td): Golf course and artificial water bodies in golf course (Gc), Hotel and residential zones with native and introduced vegetation (Rh); Modified environments by urban development, crops and livestock (Ca): Urban zone with native and introduced vegetation (Us), Cattle pastures and agricultural fields (Cp); and, Coast dunes, beach and mangrove zones (Cbm). 